\title{
KONSEP DASAR SISTEM INFORMASI MANAJEMEN
}

Oleh :

\author{
Latifur Rasyidah (17002089) \\ Fakultas Ilmu Pendidikan, Universitas Negeri Padang \\ Email : Lathifurrasyidah18@gmail.com
}

\begin{abstract}
ABSTRAK
Banyak aktifitas manusia yang berhubungan dengan sistem informasi, entah disadari atau tidak, sistem informasi telah banyak membantu manusia. Perlu diketahui bahwa item informasi tidak harus selalu berbentuk kompleks, namun juga bisa berbentuk sederhana. Sistem tersebut hanya digunakan untuk mencatat transaksi penjualan dan melibatkan satu orang saja, melalui sebuah komputer. Laporan digunakan untuk menganalisis tentang datadata yang diperoleh. Dilihat dari penjelasan diatas sudah dapat disimpulkan bahwa sistem informasi dalam manajemen sangat penting demi memudahkan perkerjaan dengan waktu yang relatif singkat.
\end{abstract}

Kata kunci : Sistem, infrmasi, manajemen.

\section{PENDAHULUAN}

Istilah Sistem Informasi Manajemen (SIM) telah banyak didefenisikan oleh para ahli manajemen dan komputer dengan cara pandang yang berbeda-beda. Istilah SIM tekah dikenal sejak tahun 1960-an. Konsep SIM saat itu berkembang seiring dengan perkembangan penggunaan teknologi komputer. Saat itu, prkembangan teknologi komputer telah memberikan kesadaran baru bahwa aplikasi komputer harus diterapkan untuk menghasilakn informasi yang dapat digunakan sebagai alat pengambilan keputusan manajemen.

Perkembangan sistem informasi manajemen telah meneyebabakan terjadinya perubahan sukup signifikan dalam pola pegambilan keputusan yang dilakuikan oleh manajemen baik 
pada semua jenjang. Perkembangan ini juga telah menyebabkan perubahan-perubahan peran dari para manajer dalam pengambilan keputusan.

\section{PEMBAHASAN}

\subsection{PENGERTIAN SIM}

Sistem informasi manajemen adalah suatu sistem perencanaan di dalam perusahaan yang melibatkan pengendalian internal seperti pemanfaatan sumber daya, dokumen, dan teknologi.

Menurut James AF Stoner sistem informasi manajemen adalah metode formal yang memberikan pihak manajemen sebuah infomasi yang tepat waktu, dapat dipercaya, dan dapat medukung proses pengambilan keputusan bagi perencanaan, pengawasan, serta fungi operasi sebuah organisasi yang lebih efektif.

Menurut Nash dan Robert, manajemen sistem informasi adalah kombinasi dari user/orang, teknologi, media, prosedur, dan juga pengendalian, yang memiliki tujuan tertentu. Tujuannya adalah untuk mendapatkan jalur komunikasi, memproses tipe transaksi, dan memberi sinyal kepada manajemen terhadap kejadian di internal suatu organisasi/ perusahaan.

Menurut Danu Wira Pangestu, manajemen sistem informasi adalah kumpulan dari interaksi sistem-sistem informasi yang bertanggung jawab mengumpulkan dan mengolah data untuk menyediakan informasi yang berguna bagi semua tingkatan manajemen di dalam kegiatan perencanaan dan pengendalian.

Jadi, dapat disimpulkan bahwa Sistem Informasi Manajemen merupakan sistem yang direncanakan untuk mengumpulkan, menyimpan, dan menyebarluaskan data berupa informasi yang dibutuhkan untuk melaksanakan berbagai fungsi manajemen. 


\subsection{TUJUAN SISTEM INFORMASI MANAJEMEN}

1. Pengumpulan data dapat menyedakan informasi yang bisa mendukung pengambilan keputusan.

2. Informasi berguna dalam perencanaan, pengendalian, evaluasi dan juga perbaikan lanjutan.

3. Sistem informasi bisa dipergunakan sebagai dasar untuk perhitungan harga produk, jasa maupun untuk tujuan lainnya sesuai yang diinginkan manajemen.

\subsection{MANFAAT SISTEM INFORMASI MANAJEMEN}

1. Meningkatkan efisiensi dan efektivitas data secara akurat dan realtime.

2. Memudahkan pihak manajemen untuk melakukan perencanaan, pengawasan, pengarahan, dan pendelegasian kerja kepada semua departemen yang memiliki hubungan atau koordinasi.

3. Meningkatkan kualitas sumber daya manusia, karena unit sistem kerja yang terkoordinasi dan sistematis.

4. Meningkatkan produktivitas dan penghematan biaya dalam organisasi.

\subsection{IMPLEMENTASI SISTEM INFORMASI MANAJEMEN}

Sistem Informasi Manajemen melakukan proses manajemen disuatu organisasi misalkan disekolah yakni dimulai dengan melakukan kegiatan perencanaan denagn mendapatkan data dan pencatatan data menggunakan SIM, pengorganisasian yang juga dilakukan dengan bantuan SIM , pelaksanaan dan pengevaluasian yang mana dalam tiap-tiap langkah tersebut terdapat peran Sistem Informasi Manajemen yang sangat mempengaruhi jalan proses manajemen disuatu organisasi yang bersangkutan. 


\section{KESIMPULAN}

Sistem informasi manajemen adalah suatu sistem perencanaan di dalam perusahaan yang melibatkan pengendalian internal seperti pemanfaatan sumber daya, dokumen, dan teknologi.

Tujuan dari Sistem Informasi Manajemen ini diantaranya :

1. Pengumpulan data dapat menyedakan informasi yang bisa mendukung pengambilan keputusan.

2. Informasi berguna dalam perencanaan, pengendalian, evaluasi dan juga perbaikan lanjutan.

3. Sistem informasi bisa dipergunakan sebagai dasar untuk perhitungan harga produk, jasa maupun untuk tujuan lainnya sesuai yang diinginkan manajemen.

Sistem Informasi Manajemen ini juga terdapat manfaat dalam penggunannya, yaitu :

1. Meningkatkan efisiensi dan efektivitas data secara akurat dan realtime.

2. Memudahkan pihak manajemen untuk melakukan perencanaan, pengawasan, pengarahan, dan pendelegasian kerja kepada semua departemen yang memiliki hubungan atau koordinasi.

3. Meningkatkan kualitas sumber daya manusia, karena unit sistem kerja yang terkoordinasi dan sistematis.

4. Meningkatkan produktivitas dan penghematan biaya dalam organisasi. 


\section{DAFTAR PUSTAKA}

https://www.maxmanroe.com/vid/manajemen/sistem-informasi-manajemen.html 